\title{
Retraction Note: Artificial intelligence-based plant environment detection in coastal areas and B2C e-commerce network marketing
}

\section{Ying $\mathrm{Cao}^{1}$}

Published online: 23 November 2021

C) Saudi Society for Geosciences 2021

Retraction Note: Arabian Journal of Geosciences (2021) 14: 996 https://doi.org/10.1007/s12517-021-07352-4

The Editor-in-Chief and the Publisher have retracted this article because the content of this article is nonsensical. The peer review process was not carried out in accordance with the Publisher's peer review policy. The author has not responded to correspondence regarding this retraction.

The original article can be found online at https://doi.org/10.1007/ s12517-021-07352-4

Ying Cao

caoying9328@163.com

1 School of Economics and Management, Anhui University of Science and Technology, Huainan 232001, China 